\title{
THE DETERMINATION OF VEGETABLE PRICING IN THE SUPERMARKET IN YOGYAKARTA
}

\author{
Suci Miranda ${ }^{1}$, Nur Aini Masruroh ${ }^{2}$ \\ Department of Mechanical and Industrial Engineering, Faculty of Engineering ${ }^{l)}$, \\ Department of Industrial Engineering, Faculty of Industrial Engineering ${ }^{2)}$ \\ Gadjah Mada University ${ }^{l)}$, Islamic University of Indonesia ${ }^{2}$ \\ Jl. Teknika Sardjito ${ }^{1)}$, Jl.Kaliurang Km.14,5 ${ }^{2)}$ Yogyakarta \\ Email:suci.yudi@gmail.com ${ }^{1}$,aini@ugm.ac.id
}

\begin{abstract}
ABSTRAK
Penelitian ini menjelaskan faktor - faktor yang mempengaruhi penentuan harga sayuran di supermarket di Yogyakarta. Diketahui bahwa harga sayuran di supermarket merupakan penjumlahan dari harga sayuran supplier dan mark up dari harga supplier tersebut. Hasil penelitian menunjukkan bahwa harga supplier merupakan salah satu variabel yang berpengaruh secara langsung terhadap harga sayuran di supermarket. Faktor - faktor yang mempengaruhi besaran mark up merupakan data kualitatifberdasarkan hasil wawancara dengan supplier dan survery di supermarket: segmentasi konsumen, pengaruh harga pasar, pengaruh harga impor, dan packaging. Hasil PCA memberikan informasi variabel penting terhadap besaran mark up harga sayuran yaitu Pengaruh Harga Pasar, Pengaruh Harga Impor, dan Packaging. Ketiga variabel ini berkorelasi tinggi baik terhadap mark up maupun harga sayuran di supermarket. Segmentasi Pasar tidak berkorelasi secara signifikan terhadap besaran mark up dan harga sayuran di supermarket. Terakhir, dengan menggunakan Partial Least Squares (PLS) dibangun model matematis penentuan harga sayuran di supermarket. Model 1 dengan 25 data dan Model 2 dengan 14 data sayuran. Y sebagai mark up, dan X adalah variabel Segmentasi Konsumen, Pengaruh Harga Pasar, Pengaruh Harga Impor, dan Packaging. Diberikan contoh perhitungan harga sayuran di supermarket menggunakan model yang dibangun.
\end{abstract}

Kata kunci : Faktor Penentu Harga Sayuran Non Organik, Pengambilan Keputusan, Supermarket, Yogyakarta, PCA, PLS.

\section{INTRODUCTION}

Fresh vegetables are provided both at traditional markets and modern markets such as supermarkets. Comparing to the sale price of vegetables, supermarket and traditional market apply a different pricing strategy. The sale price is a very important variable for retailers and consumers. For retailers, the sale price setting affect demand and profits. While for consumers, it influences the consumer's decision of a product offered.

Some previous studies of consumer purchasing behaviour in supermarket explained that price is one of attributes when they consider purchasing a product (McLaughlin, 2004; Adiyoga, 2011; Purnama et al., 2012; Dasipah, 2010). According to Chen and $\mathrm{Hu}$ (2013), the vegetable industry is an industry with strong concept of supply chain.
By potraying each node of vegetable supply chain, an effective analysis of great fluctuations in the prices of vegetables can be conducted. Wholesalers, one node of vegetable supply chain in China, plays a role in fueling great fluctuations in the price of vegetables. They need to hire warehouse rental fees, processing fees, packaging fees, handling fees, and other miscellaneous fees. Macroeconomic policies has also become a reason for great fluctuations in the prices of vegetables. One of them is the currency factor which is related to inflation.

Supermarket plays a major role in food production in a number of ways including developing a range of supermarket own brand products and the setting of safety, quality, and environmental sustainability standards for farmers and food manufactures (Burch et al., 2013). 
Mclaughlin (2004) explained the major factors affecting the complicated price of fresh fruits and vegetables in the supermarket channel. Based on economist and marketer, value and price have different definition that influence the consumer purchasing decision. Consumers are seeking a wide variety of attributes when they consider produce purchases. Price certainly is one attribute in their evoked set, but so is convenience,quality, information, taste, safety, and nutrition.

Supermarket addes some amount of money into the purchase price. Vegetables margin of marketing is higher than fruits and paddy due to inequality of supply and demand. Basically, the vegetable margin of marketing is the total of marketing costs (transportation fee, storage fee, sortation fee, grading fee) and the expected profit (Irawan, 2007). The vegetable margin includes the cost of spoilage (Baba et al., 2010). The sale price of chili is the total of purchase price, sortation fee, packaging fee, shrinkage fee, warehouse rental fee, included profit, and margin (Rum, 2011).

The study has two simple objectives: to illustrate the factors affecting the vegetable pricing in the supermarket in Yogyakarta, and to build a mathematical model using the factors illustrated. In fact, vegetables are perishable products that it's substantial for supermarket to meet consumer needs of fresh vegetables every day. Traditional markets is its competitor which also provide consumer needs of vegetables with low price. How supermarket overcomes such those conditions in order to maintain the consumer loyalty has driven this study to be conducted.

\section{DATA AND METHODOLOGY}

The data is based on both primary and secondary data. The secondary data to the mark up were collected from various published journals related to vegetables and supermarket, and published records of the
Agriculture Ministry and National Institute of Statistical. The primary information regarding purchase and sale price were collected from one experienced supplier who has been supplying vegetables for 10 years to 20 branches in Yogyakarta and Central Java, and a national chain store whose 8 branches spread around Yogyakarta. The study focuses on non-organic vegetables only. There are 39 sampels of vegetables given. The data were collected by interview method and observation at 8 branches of supermarket during January until June 2015. For analyzing data, clustering k-mean and Principal Component Analysis were used to identify and quantify the factors affecting vegetable sale price in the supermarket.

The investigation is begun by observing vegetables sale prices around 8 branches of supermarket during January until June 2015. It is found that a group of vegetables have the stable price for months, some others tend to be stable, and a few of them rapidly changed, as are shown in Table 1. Table $1 \mathrm{~b}$ shows that leek, pakcoy, celery, and spinach are sold in a stable price of $\mathrm{Rp}$. 2950,-/ 150gr, and are placed in the same shelf. Genjer leaf, green mustard, water spinach, and kenikir have the same and stable sale price of Rp. 1950,-/150gr which are sold together in another shelf. As can be seen from table $1 b$, the vegetables sale prices have little changes during the observation months. While table $1 \mathrm{~b}$ clearly shows that vegetables sale prices rapidly change in most cases. It also reflects this vegetable group function as ingredients in food recipes. 
Table 1b. Stable Sale Price

\begin{tabular}{|l|c|}
\hline \multicolumn{1}{|c|}{ Vegetables } & Supermarket (Rp) \\
\hline Green Mustard 150 Gr & 1,950 \\
Genjer Leaf & 1,950 \\
Water Spinach 150gr & 1,950 \\
Kenikir 150 Gr & 1,950 \\
Long Beans Sproutspck 200 Gr & 2,790 \\
Scallions150 Gr & 2,950 \\
Pakcoy & 2,950 \\
Celery 150 Gr & 2,950 \\
Green Spinach 150 Gr & 2,950 \\
Long Beans 200 Gr & 2,990 \\
Lencak Pck 200 Gr & 2,990 \\
Short Bean Sprouts Pck 150gr & 2,990 \\
Peeled Petai 150 Gr & 3,390 \\
Chives 150gr & 3,950 \\
Unpeeled Pickled Corn 250 Gr & 3,990 \\
Okra 150 Gr & 3,990 \\
Parsley & 4,950 \\
Oyster Mushroom 250 Gr & 5,490 \\
Chayote Whl & 5,950 \\
Peeled Pickled Corn 250 Gr & 6,990 \\
Oyong Whl & 9,950 \\
White Radish Whl & 10,950 \\
Kecipir Whl & 16,950 \\
\hline
\end{tabular}

Table 2b. Relatively Stable Sale Price

\begin{tabular}{|l|c|c|c|c|c|}
\hline Vegetables & January & February & March & March 29 & June 08 \\
\hline Broccoly Whl & 27,950 & 24,950 & 24,950 & 24,950 & 24,950 \\
Beans Pck 200 Gr & & & 2,690 & & 3,690 \\
Medium Size Potatoes Whl & & 14,950 & 14,950 & 14,950 & 14,950 \\
Chinese Cabbage Whl & 9,950 & 9,950 & 9,950 & 8,950 & 8,950 \\
Large Size Cucumber & & & 13,950 & & 7,950 \\
Bandung Tomato & & & 12,950 & 8,750 \\
Carrot Whl & & 13,950 & 7,950 & 9,990 \\
\hline
\end{tabular}

Table 3b. Sharply Fluctuated Sale Price

\begin{tabular}{|l|c|c|c|c|c|c|c|}
\hline \multicolumn{1}{|c|}{ Vegetables } & January & Februabry & March & $\begin{array}{c}\text { March } \\
\mathbf{2 9}\end{array}$ & $\begin{array}{c}\text { June } \\
\mathbf{0 2}\end{array}$ & $\begin{array}{c}\text { June } \\
\mathbf{0 8}\end{array}$ & July 21 \\
\hline Onion Whl & & & 24,950 & 37,950 & 44,950 & 44,950 & 27,950 \\
Garlic Whl & & 16,950 & 15,950 & 14,950 & 21,950 & 21,950 \\
Big Red Chiliwhl & & & 29,950 & & & & 59,950 \\
Red Chili Curly Whl & 59,950 & 29,950 & 29,950 & 23,950 & 26,950 & 26,950 & 59,950 \\
Red Chili Sauce Whl & 79.950 & 39.950 & 49.950 & 49.950 & 34.950 & 34.950 & 59.950 \\
\hline
\end{tabular}

This investigation continues to supplier and supermarket interview. The obstacles of interviewing is getting an approval from suppliers and supermarkerts related to a sensitive sale price topic. Therefore, one supplier is willing to be interviewed and a decision maker of a supermarket as well.
The first interview provides some information including the supply chain of vegetables to supermarket, the cooperation policies between supplier and supermarket, how supplier determines the vegetables sale price to supermarket, and the reasons of different sale price between supermarket and traditional market. From there, the 39 
samples of vegetables sold in supermarket are clustered using k-mean clustering in order to obtain initial factors affecting the determination of vegetable sale price in the supermarket.

As is shown in table 2, it is clearly seen the phenomenon of fluctuation in the prices of these stable price vegetables. Based on the percentage of price variance, the cluster of Beets, Kecipir, Lencak, Parsley, and Long Bean Sprouts is the smallest percentage (< $30 \%$ ). Whereas the cluster of White Radish, Oyster Mushroom, and Pakcoy have the highest percentage of price variance which is over than $80 \%$. It might be caused by the consumen segmentation that both clusters are rarely consumed as an everyday vegetable. For the difference percentage of price variance among the clustered vegetables, the supplier sale price affect the supermarket sale price. Beets and Kecipir, for example, the supplier sale price is almost Rp. 20.000,-/kg. Thus, supermarket assigns a lower percentage of price variance. So are they a few consumer segmentation. Another cluster of Green Mustard until Oyong, it posseses $30-40 \%$ of percentage of price variance. These vegetables are commonly consumed as an everyday vegetable which lead supermarket to raising less than 50\% from supplier sale price. According to the analysis of data observed, it is identified similar initial factors contributing to the supermarket sale price: supplier sale price, consumer segementation, supply and demand, and market price of vegetable. These factors need to be confirmed by another interview to both supplier and the decision maker at supermarket in order to obtain the major factors contribute to the complicated supermarket sale price.

Table 2. Clustering Result of Stable Price Vegetables

\begin{tabular}{|l|c|c|c|c|}
\hline \multicolumn{1}{|c|}{ Vegetables } & $\begin{array}{c}\text { Supp } \\
(\mathbf{R p})\end{array}$ & $\begin{array}{c}\text { SM } \\
(\mathbf{R p})\end{array}$ & $\begin{array}{c}\Delta \mathbf{\Delta} \\
(\mathbf{R p})\end{array}$ & $\begin{array}{c}\Delta \mathbf{\text { P }} \\
\mathbf{\%}\end{array}$ \\
\hline Beets Whl & 22,000 & 23,950 & 1,950 & 9 \\
Kecipir Whl & 15,000 & 16,950 & 1,950 & 13 \\
Lencak Pck 200 Gr & 2,500 & 2,990 & 490 & 20 \\
Parsley & 4,000 & 4,950 & 950 & 24 \\
Long Bean Sprouts Pck 200 Gr & 2,200 & 2,790 & 590 & 27 \\
Green Mustard 150 Gr & 1,500 & 1,950 & 450 & 30 \\
Genjer Leaf & 1,500 & 1,950 & 450 & 30 \\
Kenikir 150 Gr & 1,500 & 1,950 & 450 & 30 \\
Long Beans 200 Gr & 2,300 & 2,990 & 690 & 30 \\
Okra 150 Gr & 3,000 & 3,990 & 990 & 33 \\
Green Beans Pck 200 Gr & 2,000 & 2,690 & 690 & 35 \\
Peeled Petai 150 Gr & 2,500 & 3,390 & 890 & 36 \\
Short Bean Sprouts Pck 150 Gr & 2,167 & 2,990 & 823 & 38 \\
Chives Ikt & 2,850 & 3,950 & 1,100 & 39 \\
Water Spinach 150gr & 1,400 & 1,950 & 550 & 39 \\
Peeled Pickled Corn 250 Gr & 5,000 & 6,990 & 1,990 & 40 \\
Oyong Whl & 7,000 & 9,950 & 2,950 & 42 \\
Spinach 150 Gr & 2,000 & 2,950 & 950 & 48 \\
Celery 150 Gr & 2,000 & 2,950 & 950 & 48 \\
Squash Whl & 4,000 & 5,950 & 1,950 & 49 \\
Unpeeled Pickled Corn 250 Gr & 2,500 & 3,990 & 1,490 & 60 \\
White Radish Whl & 6,000 & 10,950 & 4,950 & 83 \\
Oyster Mushroom 250 Gr & 3,000 & 5,490 & 2,490 & 83 \\
Pakcoy & 1,500 & 2,950 & 1,450 & 97 \\
\hline
\end{tabular}


In accordance with the previous analysis, the further interviews of supplier and supemarket state that supplier sale price has influenced the supermarket sale price added by margin of supermarket. Because of the limited information access regarding the margin topic, this study could only gain the factors considered to determine the supermarket sale price: consumer segmentation, the influence of market price, and the influence of import price. Reviewing some journals related to supermarket sale price emphasizes supermarket's statement of the determination factors of vegetable pricing. This study includes packaging factor to the supermarket sale price. Packaging links to the marketing strategy of supermarket, not only a quality standard of vegetable but also one of promotion tools using by supermarket (Rundh, 2013). There is a set of values of packaging such as safety, quality, information, and taste. When a consumer purchases a bunch of Spinach which costed Rp. 2,950/150gr, the price variance of Rp. 950 informs the characteristics of Spinach consisted of the consumen segmentation (commonly used), the influence of market price, no influence of import price, and the packaging value (150gram of each bunch). Therefore, the mathematical model is formed as follows.

$\mathrm{SM}=\mathrm{Supp}+\Delta \mathrm{P}$

where,

SM = Supermarket Sale Price.

Supp = Supplier Sale Price.

$\Delta \mathrm{P} \quad=$ Delta of Price.

Based on previous studies, supermarket is supplied by suppliers or wholesalers (Blandon, 2006; Srimaneedan Routray, 2012). Supermarket interview also explains that its vegetables are supplied by 15 suppliers. Supplier sale price directly affects the supermarket sale price. Supermarket enables them to determine what will - and will not - be stocked, and on what terms: sources, quantity, quality, delivery schedules, packaging, returns policy, and above all, price and payment conditions. The supplier sale price will not be explained regarded its determinations in this study. Then, the real data of supplier sale price given is directly employed into the supermarket sale price formula without any changes. The delta of price encompasses four factors and how this delta of price allocated into each factor can be defined by modelling it using Partial Least Squares. All variables to the supermarket sale price is illustrated in a conseptual model in figure 1 .

$\mathrm{Y}=a+b_{1} X_{1}+b_{2} X_{2}+b_{3} X_{3}+b_{4} X_{4} \ldots . .(2)$

where,

$\mathrm{Y}=$ Delta of Price

$X_{1} \quad=$ Consumer Segmentation

$X_{2} \quad=$ Market Price Effect.

$X_{3} \quad=$ Import Price Effect.

$X_{4} \quad=$ Packaging.

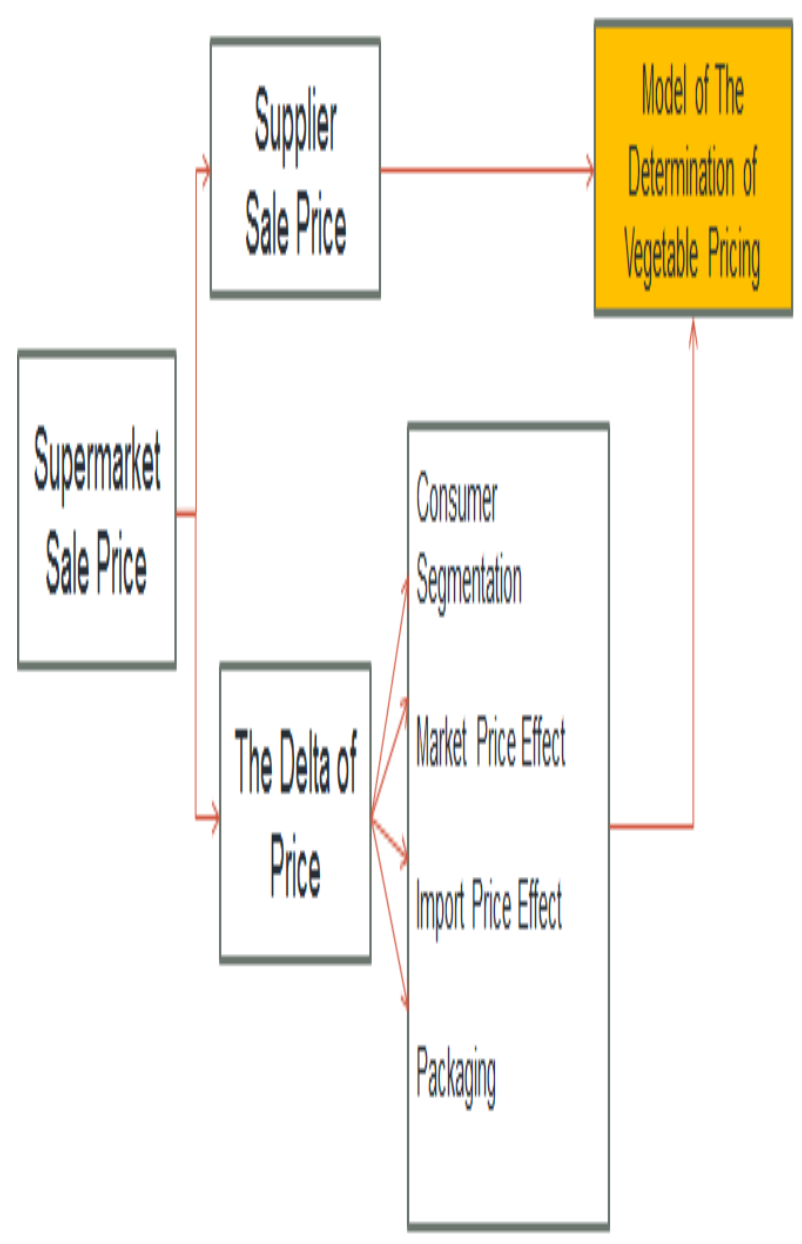

Fig 1. The Conceptual Model. 
Knowing the data regarding each attribute will make data processing easier. These variables to the supermarket sale price are identified clearly, as shown in figure 2 .

\subsection{Consumer Segmentation}

Supermarket calculates differently for each sale price of vegetablebased on the number of consumers whether it is often consumed or not. However, this consumer segmentation variable could be explained in detail by supermarket. The secondary data is needed in identifying consumer segmentation for each vegetable of sample data which is obtained from the official website of the Ministry of Agriculture related to household consumption of vegetables and journals about vegetables. According to Adiyoga (2011), 93.1\% and $80.7 \%$ of 462 respondents used the onion and red pepper almost every day. While for the potato, $67.1 \%$ of respondents consumed potato once or twice a week. The consumer segmentation data is qualitative data with ordinary attributes (ranking). The 39 samples of vegetables are categorized into 3 groups: 1 is public segmentation (many people consume it), 2 is moderate segmentation (quite many people consume it), 3 is a special segmentation (a few people consume it).

\subsection{Market Price Effect}

Mclaughlin (2004) stated that price is often used to explain sales changes. Indeed, economists teach that as price increases, the quantity demanded goes down; conversely, as price goesdown, quantity demanded (or sales) should go up. The supply of vegetables in the market affect the price of vegetables. Retailers must supply the amount of vegetables every day based on a supplier purchase order released by supermarket. If the supply of certain vegetables is reduced in the market so that the price offered by the supplier will be automatically risen. So is the sale price in supermarket. The variable of market price effect is a qualitative data and an ordinary attribute (ranking). In accordance with PASKOMNAS (National Commodity Center) data, the 39 samples of vegetables are divided into 3 groups : 1 is the vegetablesof stable price, 2 is the vegetablesof relatively stable price, and 3 is the vegetables of sharply fluctuated price. When the market price is stable, the price of several vegetables in supermarket can be set stable, as categorized in the first group. Moreover, the observation results show that some vegetable prices are stable within January to June 2015, such as Spinach, Genjer Leaf, and Green Mustard (look at Table 2).

\subsection{Import Price Effect}

Regulation of the Minister of Trade of the Republic of Indonesia (16 / M-DAG / PER / 4/2013) describes the import provisions of horticultural products including Shallot, Garlic, Onion, Chili, Carrot, Radish, Beet and Potato. Based on interviews with supermarket and supplier, the prices of imported vegetables influence the determination of their sale price. When the number of local vegetable supply in the market is reduced, the sale price of vegetables is rising. This insufficient of vegetables supply can be caused by crop failure due to weather. Thus, it cannot meet consumer demand of vegetables in Indonesia. To change this situation, the supply of imported vegetables could support the consumer demand of vegetables,so that the balance of supply and demand of vegetable is reached, and great fluctuations in the price of vegetable is eased. The worse is the limitation of supply of imported vegetables by government which can rise the sale price of local vegetables due to insufficient supply to the consumer demand. So the impact of imported vegetables price can not be ignored. Related to the supply chain of vegetables to supermarket, when the sale price of vegetables rose at market, it will be forwarded by supplier to supermarket, so will supermarket to its consumers. The variable of import price effect is a qualitative data with attributes binary ( 1 or 0$)$. In this study, 39 samples of 
vegetables are identified and categorized into 2groups: the imported vegetables price affect the market sale price with the number 1 and the imported vegetables price has no influence by the number 2 .

\subsection{Packaging}

It is important to notice that quality of vegetable can not be improved but it can only be sustained. A decrease of vegetable freshness level also can not be stopped, but it can only be prolonged. Therefore, the principle of packaging is intended to protect vegetables from damage due to mechanical (impact), temperature (hot) and physiological (slow aging). A part from the functions of protection and facilitating distribution, packaging has become a tool for fulfilling several other marketing purposes (Rundh, 2013). Rundh (2013) investigates the importance of safe and convenient packaging solutions can obviously be animportant element in the marketing strategy for any producing company. Welldesigned packages can build brand and drive sales, and obviously become an important element for building customer value and competitive advantage. Some studies have been conducted related to the innovation of packaging contributes to the marketing strategy and the packaging is linked to the outcome. This study addresses this issue by involving packaging variable to supermarket sale price determination.

Supplier is required to package some vegetables ordered using supermarket standard, such as Broccoli, Oyster Mushroom, and Chinese Cabbage. Indeed, there is a cost of packaging, but it obviously turns out some value-added fresh produce to the supermarket marketing. When consumers purchase broccoli sold in wrapping plastic, price certainly isone attribute in their evoked set, but so is convenience, quality, information, taste, nutrition, and even safety. So consumers purchase a variaty of attributes in a Broccoli. Packaging variable is qualitative data with attributes binary ( 1 or $0)$. Number 1 is for packed vegetables and number 0 is for vegetables with no pack.

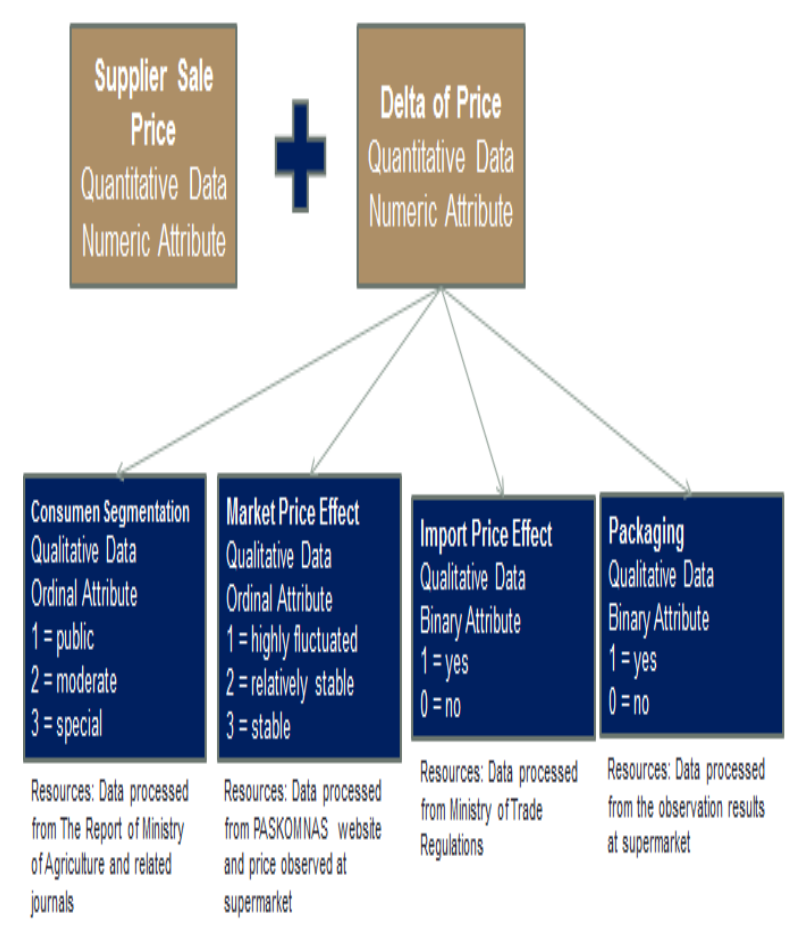

Fig 2. Characterization of Variables

\section{RESULT AND DISCUSSION}

The supplier sale price and supermarket sale price show a very strong correlation (0.958). It has been explained that supplier sale price directly affect the price of vegetables in the supermarket. Similar resultis shown by the strong correlation (0.770) between delta of price (Y) and supermarket sale price (SM). Of course, the delta of price is the price variance between supplier sale price and supermarket sale price. Related to the formula of $\mathrm{Y}$ and SM, the consumer segmentation variablehas no significant correlation to both Y (-0.233) and SM (-0.136). The Market Price Effect and Packaging give a negative and significant correlation to Y $(-0.505 ;-5.05)$ and SM ($0.515 ;-0.497)$. The minus means that the variable inversely associated. If the market price decreases, for example, the delta of price will be larger and so will the supermarket sale price. While the Import Price Effectis the only variable which has a positive and significant relationship to $\mathrm{Y}$ (0.440) and SM (0.514) called directly correlated. If the import price goes up, the delta of price will be higher as well as the supermarket sale price. 


\subsection{Principal Component Analysis}

Circle of Correlation provides relationships information among variables (Figure 3) which is confirmed with a correlation matrix between variables in Table 3. The Market Price Effect (HP) and Packaging (P) are adjacent and negatively related to the Import Price Effect (HI). Consumen Segmentation (S) variable is simply related to the Market Price Effect. The correlation test by using Chi - square states that consumer segmentation is not correlated with import price effect and packaging. However, consumer segmentation is positively correlated with market price effect. The market price effect is correlated with bothimport price effect and packaging. A strong negative correlation is also shown between the import price effect and packaging.

Table 3. Correlation Matrix

\begin{tabular}{|l|c|c|c|c|}
\hline Variables & CS & MPE & IPE & P \\
\hline CS & 1 & 0,457 & $-0,255$ & 0,305 \\
MPE & 0,457 & 1 & $-0,698$ & 0,716 \\
IPE & $-0,255$ & $-0,698$ & 1 & $-0,766$ \\
P & 0,305 & 0,716 & $-0,766$ & 1 \\
\hline
\end{tabular}

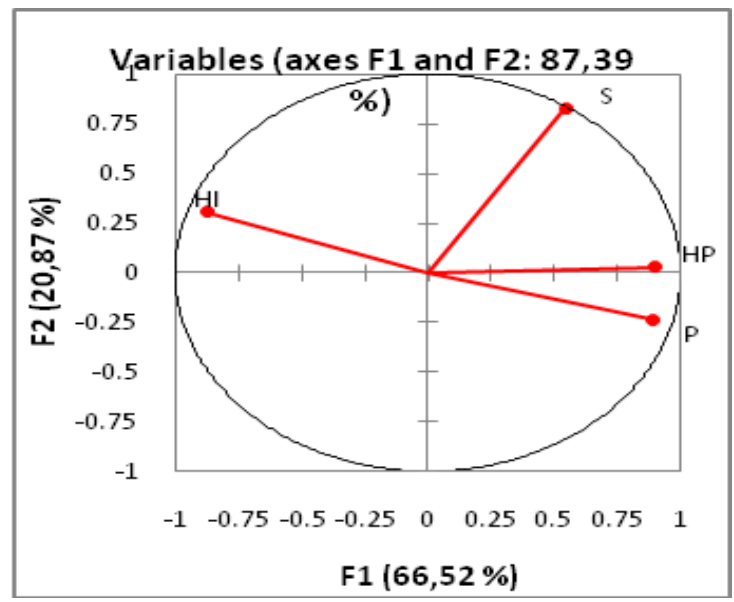

Figure 3. Circle of Correlation.

Market price effect and import price effect are negatively correlated due to the regulation of the import provisions of horticultural products. It needs to note that correlation does not imply causality. In this case, both variables are actually causally linked to a third variable, namely, vegetable supplies.

For the variables, the principal component analysis produced two unique dimensions. The first factor is defined largely by market price effect, import price effect, packaging. These three variables load positively onto this dimension. Consumer segmentation defines the second dimension, loading positively onto factor two.

Table 4. Loading Factors

\begin{tabular}{|l|l|l|}
\hline & Factor 1 & Factor 2 \\
\hline Consumen Segementation & 0,297 & 0,684 \\
Market Price Effect & 0,810 & 0,001 \\
Import Price Effect & 0,761 & 0,094 \\
Packaging & 0,793 & 0,056 \\
\hline
\end{tabular}

In the principal component analysis, the dataset of vegetables is mainly conculed into factor 1 , as can be seen in Table 5a. For vegetables which market price and import price affect them (category 1 and 1), and vegetables are not packed (Packaging $=0$ ), the delta of price is depended on the condition of market price and import price. For example, Onion, if the amount of supply in the market is reduced, then the market price will rise. However, if the amount of supply in the market is reduced and imported onions are supplied to the market, market prices may go down. This situation influence the determination of the delta of vegetable prices, and ultimately it will have an impact on the price of vegetables in the supermarket.

Market price and import pricehas no effect onto the vegetables (MPE $=3$ and IPE $=0$ ), the delta of price will be adjustedby the supplier sale price. When a supplier sale price is high (eg. Kecipir Rp. 15,000,-/kg), a small delta of price will be set (13\%), vice versa. Pakcoy is elevated $97 \%$ from Rp. $1,500,-/ 150$ gr to Rp. 2,950/150gr. Both Pakcoy and Kecipir are not daily consumed $(C S=3)$. Thus, supermarket may define its vegetable sale price depended on the supplier sale price of each vegetable. In order to attract consumen of these particular 
vegetables, Packaging givesan added value to the appearance quality of vegetables (the value of marketing).

Indeed, there are chief vegetables sold by supermarket such as onions, garlic, chili, spinach, potatoes, and tomatoes. Yet, supermarket alsomust provide other particular vegetables to meet consumer demand like white radish, kecipir, kenikir, beets, and genjer leaf. Therefore, supermarket is able to set a stable price for vegetables with no market price effect and import price efffect.

Table 5a. Vegetable Characteristics on to Factor 1

\begin{tabular}{|l|c|c|c|c|c|c|c|c|}
\hline \multicolumn{1}{|c|}{ Vegetables } & $\begin{array}{c}\text { Supp } \\
(\mathbf{R p})\end{array}$ & $\begin{array}{c}\text { SM } \\
(\mathbf{R p})\end{array}$ & $\begin{array}{c}\Delta \mathbf{P} \\
(\mathbf{R p})\end{array}$ & $\begin{array}{c}\Delta \mathbf{\%} \\
\boldsymbol{\%}\end{array}$ & $\mathbf{C S}$ & $\mathbf{M P E}$ & $\mathbf{I P E}$ & $\mathbf{P}$ \\
\hline Garlic Whl & 15,500 & 16,950 & 450 & 3 & 1 & 1 & 1 & 0 \\
Onion Whl & 34,000 & 37,950 & 3,950 & 12 & 1 & 1 & 1 & 0 \\
Kecipir Whl & 15,000 & 16,950 & 1,950 & 13 & 3 & 3 & 0 & 1 \\
Lencak 200 Gr & 12,500 & 14,950 & 2,450 & 20 & 3 & 3 & 0 & 1 \\
Red Chili Curly Whl & 20,000 & 23,950 & 3,950 & 20 & 1 & 1 & 1 & 0 \\
Genjer Leaf & 1,500 & 1,950 & 450 & 30 & 3 & 3 & 0 & 1 \\
Kenikir 150 Gr & 1,500 & 1,950 & 450 & 30 & 3 & 3 & 0 & 1 \\
Medium Size Potatoes Whl & 11,500 & 14,950 & 3,450 & 30 & 2 & 1 & 1 & 0 \\
Chives 150gr & 2,850 & 3,950 & 1,100 & 39 & 3 & 3 & 0 & 1 \\
Peeled Pickled Corn 250gr & 5,000 & 6,990 & 1,990 & 40 & 2 & 3 & 0 & 1 \\
Celery 150 Gr & 2,000 & 2,950 & 950 & 48 & 3 & 3 & 0 & 1 \\
Big Green Chili Whl & 16,000 & 24,950 & 8,950 & 56 & 2 & 1 & 1 & 0 \\
Unpeeled Pickled Corn & 2,500 & 3,990 & 1,490 & 60 & 2 & 3 & 0 & 1 \\
Bandung Tomatoes & 8,000 & 12,950 & 4,950 & 62 & 1 & 1 & 0 & 0 \\
Carrot Whl & 8,500 & 13,950 & 5,450 & 64 & 1 & 2 & 1 & 0 \\
Red Chili Sauce Whl & 30,000 & 49,950 & 19,950 & 67 & 1 & 1 & 1 & 0 \\
Pakcoy & 1,500 & 2,950 & 1,450 & 97 & 2 & 3 & 0 & 1 \\
Big Red Chiliwhl & 14,500 & 29,950 & 15,450 & 107 & 1 & 1 & 1 & 0 \\
\hline Average & 11,242 & 15,677 & 4,379 & 44 & \multicolumn{1}{|c}{} \\
\hline
\end{tabular}

Table 5b. Vegetable Characteristics on to Factor 2

\begin{tabular}{|l|c|c|c|c|c|c|c|c|}
\hline \multicolumn{1}{|c|}{ Vegetables } & $\begin{array}{c}\text { Supp } \\
(\mathbf{R p})\end{array}$ & $\begin{array}{c}\text { SM } \\
(\mathbf{R p})\end{array}$ & $\begin{array}{c}\Delta \mathbf{P} \\
(\mathbf{R p})\end{array}$ & $\begin{array}{c}\Delta \mathbf{P} \\
\mathbf{\%}\end{array}$ & $\mathbf{C S}$ & $\mathbf{M P E}$ & $\mathbf{I P E}$ & $\mathbf{P}$ \\
\hline Beets Whl & 22,000 & 23,950 & 1,950 & 9 & 3 & 3 & 1 & 0 \\
Long Beans Sproutspck 200gr & 11,000 & 13,950 & 2,950 & 27 & 1 & 3 & 0 & 1 \\
Green Mustard 150 Gr & 1,500 & 1,950 & 450 & 30 & 1 & 3 & 0 & 1 \\
Long Beans 200 Gr & 2,300 & 2,990 & 690 & 30 & 1 & 3 & 0 & 1 \\
Short Bean Sprouts Pck 150 Gr & 13,000 & 17,940 & 4,940 & 38 & 1 & 3 & 0 & 1 \\
Water Spinach150gr & 1,400 & 1,950 & 550 & 39 & 1 & 3 & 0 & 1 \\
Spinach 150 Gr & 2,000 & 2,950 & 950 & 48 & 1 & 3 & 0 & 1 \\
Chayote Whl & 4,000 & 5,950 & 1,950 & 49 & 1 & 3 & 0 & 1 \\
White Radish Whl & 6,000 & 10,950 & 4,950 & 83 & 3 & 3 & 1 & 0 \\
\hline Average & 8,715 & 13,250 & 4,531 & 53 & & &
\end{tabular}

Table $5 \mathrm{~b}$ presents the vegetables group which consumer segementation is the main variable. In thic factor 2 , vegetables are largely consumed daily $(\mathrm{CS}=1)$ and are not affected by the market price (MPE = 3). If the market price is stable, supermarket will also be able to determine a stable sale price. The delta of price is defined from $30 \%$ to 
$40 \%$ so that consumers can purchase vegetables in affordable price. For vegetables of consumer segmentation type 3 such as white radish and beets, the delta of price determination is depended on the supplier sale price. If the supplier sale price is high (e.g.,Beets is Rp. 22,000, - / kg), the supermarket will chargelittle higher than the supplier sale price $(9 \%)$. Conversely, if the supplier sale price is not expensive (e.g., Radish Rp. 6.000, - / kg), supermarket is possible to set higher delta of price $(83 \%)$. The consumer segmentation type 3 is exactly consistent with the supplier sale price of each vegetable.

\subsection{Develop of Model of Sale Price Determinatin using Partial Least Squares}

There are two mathematical models constructedto estimate the supermarket sale price using the Partial Least Squares (PLS). The first model is built by 25 data of vegetables, and the second model is a validity of the first model which is constructed by 14 data of vegetables. These datasets must be normalized because of the different type of attribute (the delta of price is quantitative and the variables are qualitative).

\section{Mathematical model 1}

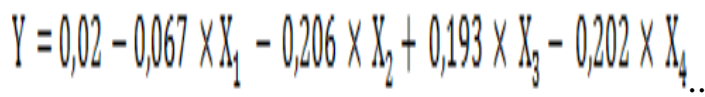

Based on the first model, market price effect $\left(X_{2}\right)$ and packaging $\left(X_{4}\right)$ are negatively correlated to the delta of price (Y). Import price effect $\left(X_{3}\right)$ is positively related to $Y$. While consumen segmentation $\left(X_{1}\right)$ does not have a considerable influence on to $\mathrm{Y}(0,067)$. It indicates that market price effect $\left(X_{2}\right)$ is the most dominant variable to the determination of delta of price $(0,206)$ as well as the negative correlation to $\mathrm{Y}$. The market price effect and import price effect are negatively correlated which is the same result of principal component analysis.

\section{Mathematical model 2}

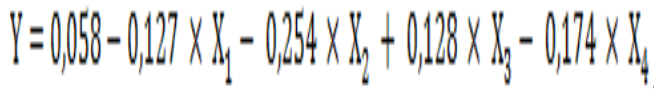

The second model shows that market price effect $\left(X_{2}\right)$ is negatively correlated to $\mathrm{Y}$ with the highest coefficient (0.254). So is the second model, the variabel of import price effect affect $\left(X_{3}\right)$ is positively related to related Y. Consumen segmentation $\left(X_{1}\right)$ is negatively related to $\mathrm{Y}$ with the smallest coefficient among others. It is clelarly explained that the market price effect and import price effect are negatively correlated due to the government regulation.

Table 6. The Validity Result

\begin{tabular}{|ll|l|}
\hline & \multicolumn{1}{c|}{ Model 1 } & \multicolumn{1}{|c|}{ Model 2 } \\
\hline MSE & 1.02124 & 0.11279 \\
MAPE & 7.910057 & 0.728572 \\
SSE & 25.53099 & 1.579059 \\
SST & 67.93566 & 3.527237 \\
R Squared & 0.624189 & 0.552324 \\
adj R Squared & 0.549026 & 0.353357 \\
\hline
\end{tabular}

Overall, the first and second model have the same correlation result to the determination of delta of price. The validity result of both models are presented in Table 6. The selected model is based on the smallest MAPE. MAPE of model 1 is 7.91 and model 2 is 0.73 . Clearly, model 2 would be preferred in order to estimate the delta of price of supermarket sale price.

\subsection{The Limitedness of The Model}

This research is restricted the relatively one one supermarket and supplier as well as limited information available. It can not defined whether the delta of price is a margin or mark - up. Furthermore, the decision maker of supermarket gave slighlty information related to the factors considered of sale price determination. Thus, the model built comprises limited information of variables which affect the supermarket sale price but the supplier sale price. The delta of 
price of vegetables (Y) is set constant each month because the vegetable characteristic may not be changed. For example, red chili, it is clear that red chili is consumed by many households $(\mathrm{CS}=1)$, the price is influenced by market price and import price $(\mathrm{MPE}=1$, IPE = 1), and it is sold without packed $(\mathrm{P}=$ $0)$. In order to define the qualitative data of variables (CS, MPE, IPE, and P), the secondary data is needed by using related journals and the website of the Agriculture Ministry and National Institute of Statistical of Indonesia. There are also personal definitions in examining the qualitative variables. Indeed, the weak correlations found have suggested that there are fundamental variables in the determination of vegetable pricing in the supermarket. A larger number of supermarket and supplier involved, as well as the number of vegetables observed, would allow a researcher to emerge some different categories and more relationships among them related to the determination of vegetable pricing in the supermarket.

\section{CONCLUSIONS}

This paper briefly puts forth the factors that explain the pricing of vegetables in the supermarket. It finds some influenced variables in determining the sale price of vegetables by a decision maker in supermarket. The supplier sale price directly influences the supermarket sale price proved by the correlation matrix. It also estimates the sale price formulation of vegetables using the variables emerged. The import price and market price are proven affecting the delta of price which the import price is positively related to it. It is found that consumen segmentation variable does not correlated to the delta of price. This paper can illustrate the way of supermarket decision making of its vegetable sale price.

Since the vegetables are purchased in the supermarket, there are several opportunities to better understand what motivates consumers in their weekly shoppingtrip to purchase fresh vegetables.In addition to price, examination is required of the importance of brands, convenience, labeling, organic standards, information (e.g., recipes), demonstrations, safety, and more (McLaughlin, 2004).

As mentioned previously, the formula of vegetable sale price possesses several restricted information that the delta of price set constant. It could be biased since the supplier is also considered the similar variables in determining its sale price such as the market price effect, the import price effect, and packaging. Research which provides some categories of variables would be useful to the formulation of vegetable pricing in the supermarket. Additionally, it is supermarkets who decide what goes ontotheir produce shelves andwhat is promoted in what quantities to their shoppers.

Finally, although it presents the result of the finite model estimation, it is clear that supplier sale pric, market price effect, and import price effect are a few of major factors in determining the vegetable pricing in the supermarket. Indeed, the supplier and supermarket relationships is a complex condition as well as the system complexity rapid pace necessitated by the highly perishable nature of most fresh vegetables. It is important that future research could resolve this issue, laying out guidelines for estimating the vegetable price in different situations.

\section{Acknowledgements}

I would like to express sincere thanks to Prof. Ir. Jamasri, Ph.D, Ir. Subagyo, Ph.D, Dr. M. K. Herliansyah, ST, MT, and Nur Aini Masruroh, ST, M.Sc., Ph.D., as the Head of Department of Mechanical and Industrial Engineering, Secretary of Department of Mechanical and Industrial Engineering, Head of Industrial Engineering Program, and my academic supervisor respectively. 


\section{REFERENCES}

Adiyoga, W, Faktor - faktor yang Mempengaruhi Perilaku dan Keputusan Konsumen untuk Membeli Kentang, Bawang Merah, dan Cabai Merah, J.Hort., Vol.21, No.3, 2011.

Baba, S.H., Wani, M.H., Wani, S.A., dan Yousuf, S, Marketed Surplus and Price Spread of Vegetables in Kashmir Valley, Agricultural Economics Research Review, Vol.23, pp.115-127, 2010.

Blandon, J, Supermarket Supply Chain for Fresh Fruits and Vegetables: Opportunities and Challenges for Small Farmers, Thesis, University of Guelph, 2006.

Buletin Konsumsi Pangan, Pusat Data dan Sistem Informasi Pertanian, Vol.5, No. 2-4, 2014.

Buletin Analisis Perkembangan Harga Komoditas Pertanian, Pusat Data dan Sistem Informasi Pertananian Sekretariat Jenderal, Kementerian Pertanian, 2015.

Burch, D., Dixon, J., dan Lawrence, G., Introduction to Symposium on The Changing Role of Supermarkets in Global Supply Chains: from Seedling to Supermarket: Agri food Supply Chains in Transition, Agric Hum Values, Vol. 30, pp. 215-224, 2013.

Chen, Shuang, dan Hu, Lijia, Why Are There Great Fluctuations in The Prices of Vegetables?, Asian Agricultural Research, Vol.5, No.3, pp.1-6, 2013.

Dasipah, E., Budiyono, H., dan Julaeni, M., Analisis Perilaku Konsumen Dalam Membeli Produk Sayuran di Kota Bekasi, Jurnal Agribisnis dan Pengembangan Wilayah, Vol.1, No.2, 2010.
Irawan, Bambang, Fluktuasi harga, Transmisi harga dan Marjin pemasaran Sayuran dan Buah, Analisis Kebijakan Pertanian, Vol.5, No.4, pp. 358-373, 2007.

McLaughlin, E.W, The Dynamics of Fresh Fruit and Vegetable Pricing in The Supermarket Channel, Preventive Medicine, Vol.39, pp. 81-87, 2004.

Purnama, H.A., Hartono, G., dan Sunaryanto, L.T, Permintaan Sayuran Segar dan Faktor yang Mempengaruhi di Supermarket Alpha Semarang, AGRIC, Vol.24, No.1, pp. 21-27, 2012.

Rum, Mokh, Analisis Marjin Pemasaran dan Sensivitas Cabai Besar di Kabupaten Malang, Embryo, Vol. 8, No. 2, 2011.

Rundh, Bo, Linking Packaging to Marketing: How Packaging is Influencing The Marketing Strategy, British Food Journal, Vol.115, No.11, 2013.

Srimanee, Y., dan Routray, J.K, The Fruit and Vegetable Marketing Chains in Thailand: Policy Impacts and Implications, International Journal of Retail \& Distribution Management, Vol. 40, No. 9, pp. 656-675, 2012. 